\title{
EFFECT OF HIGH PRESSURE PROCESSING ON MICROBIAL LOAD IN PORK
}

\author{
Sanita Sazonova, Ruta Galoburda, Ilze Gramatina \\ Latvia University of Agriculture \\ sanita.sazonova@1lu.1v
}

\begin{abstract}
Fresh meat is a highly perishable product due to its biological composition as it serves as an ideal environment for the growth and propagation of microorganisms and common food-borne pathogens. High pressure processing (HPP) is a cold pasteurization treatment to extend shelf-life while preserving the sensory and nutritional characteristics of the product. The aim of this research was to evaluate the effects of HPP on the fresh porcine Musculus longissimus lumborum microbial load and related physical properties ( $\mathrm{pH}$, water activity $\mathrm{a}_{\mathrm{w}}$, and moisture content). Vacuum packed meat samples were treated at 50,100, 200,300, 400, and $500 \mathrm{MPa}$ for 1, 5, and $15 \mathrm{~min}$ in a high-pressure processor ISO-Lab S-FL-100-250-09-W (Stansted Fluid Power Ltd., UK). Pressure treatment above $300 \mathrm{MPa}$ resulted in a significant $(\mathrm{p}<0.05)$ decrease of total plate count. However, the studied pressurizing time had no significant effect on microbial lethality at the same pressure applied. Other important parameters such as water activity, moisture, and $\mathrm{pH}$ were determined as they directly affect microorganism growth and resistance to pressure. A slight increase in pork $\mathrm{pH}$ was observed with increased pressure. No significant changes in water activity and moisture content were observed as a result of high pressure treatment. For future researches it would be important to evaluate the dynamics of microbial growth during storing as part of cells after pressure treatment are injured and not eliminated immediately; therefore, microbial count may further decrease during cold storage.
\end{abstract}

Key words: high pressure processing (HPP), pork quality, total plate count.

\section{Introduction}

Pork ranks first among all meat sources, and it is considered to be approximately $40 \%$ of global meat consumption (Keenan, 2016). The diverse and rich nutrient composition of meat is a good media for the growth and proliferation of both meat spoilage microorganisms and common food-borne pathogens. Regarding this fact, it is essential to use preservation methods to maintain meat safety and quality during its storage (Aymerich, Picouet, \& Monfort, 2008). Consumers have growing concerns for food quality and prefer healthy, minimally processed, fresh-like food products with natural flavour and taste with extended shelf-life (Yordanov \& Angelova, 2010). Therefore, the alternative non-thermal preservation technology such as high pressure processing (HPP) is considered to match these demands without compromising safety (Aymerich, Picouet, \& Monfort, 2008).

HPP has got main interest as it has been demonstrated to be an effective inactivation technique for a variety of pathogenic microorganisms, spoilage microorganisms, yeasts, moulds, as well as qualitydeteriorating enzymes, without heat treatment or chemical preservatives (Yordanov \& Angelova, 2010; Salvi, Gosavi, \& Karwe, 2016) with minimal or no changes of the sensory or nutritional characteristics of the product and potential to extend shelf-life (Sun \& Holley, 2010; Zhou, Xu, \& Liu, 2010; Jofré \& Serra, 2016). The use of high-pressure technology in food processing has gained its popularity recently, and now is gradually being adopted for the products processing and preservation in the food industry (Huang et al., 2017). The number and variety of meat and meat products treated with this technology has risen dramatically worldwide especially in last years
(Balasubramaniam, Barbosa-Cánovas, \& Lelieveld, 2016). As a result of high demand for this technology, the recent progress in equipment design has improved access to high-pressure devices for enterprises with different capacities (Simonin, Duranton, \& de Lamballerie, 2012). The basic principles that determine the behaviour of foods during HPP technology are Le Chatelier's principle, principle of microscopic ordering, and isostatic principle (Yordanov \& Angelova, 2010). The isostatic transmission of pressure provides the instantaneous treatment to the processed product with no gradient, resulting in the uniform pressure distribution irrespective of the size and geometry of the material; moreover, food can be processed at ambient or even lower temperatures (Simonin, Duranton, \& de Lamballerie, 2012).

The effectiveness of HPP for microbial control is affected by such factors as the process parameters, applied pressure, temperature, and dwell time, as well as intrinsic factors of the food itself, such as food composition, $\mathrm{pH}$, and water activity (Zhou, $\mathrm{Xu}, \&$ Liu, 2010; Patterson, 2014).

Moreover, microorganisms' response and resistance to pressure varies significantly among different genus, species and even strains of the same species, form, morphology of the cell and its growth stage (Hugas, Garriga, \& Monfort, 2002; Garriga et al., 2004; Patterson, 2005; Jofré et al., 2010). The microbial inactivation under high pressure is mainly caused by an alteration in cellular morphology and inhibition of cell division (Tonello, 2011).

Pressure levels necessary to achieve efficient microbial inactivation is not without effects on food. Among food constituents, muscle and muscle proteins are the most responsive to pressure (Sun \& Holley, 
2010). For meat and meat products elevated pressure treatment induce significant changes in the quality attributes as it has been shown to induce protein denaturation and acceleration of lipid oxidation during subsequent storage. This is due to the relatively high sensitivities to pressure of muscle glycolytic processes and of the associations between myofibrillar proteins (MacFarlane, 1985). Such modifications of meat matrix lead to colour and texture changes and decreased sensory acceptability (Simonin, Duranton, $\&$ de Lamballerie, 2012).

The aim of this research was to evaluate the effects of HPP on the fresh porcine Musculus longissimus lumborum microbial load and related physical properties $\left(\mathrm{pH}\right.$, water activity $\mathrm{a}_{\mathrm{w}}$, and moisture content).

\section{Materials and Methods}

The research was performed at Latvia University of Agriculture, Faculty of Food Technology in 20162017.

\section{Study object}

Chilled pork obtained from Musculus longissimus lumborum (Latvia) has been purchased from the local store Ltd. 'Maxima Latvia' (unpackaged; stored in chilled condition at temperature $3 \pm 1{ }^{\circ} \mathrm{C}$; maximal expiration time $24 \mathrm{~h}$ ). No breed, age, sex or premortal handling was recorded. Pork samples underwent testing of sensory parameters as the appearance, aroma, colour, and texture fit requirements of fresh meat before experiments.

\section{Preparation of meat samples}

The obtained chilled pork meat was cut in $1.0 \pm$ $0.2 \mathrm{~cm}$ thick slices across the muscle fibre and slices were divided into portions with weight of $200.0 \pm$ $0.2 \mathrm{~g}$ each, packed in the vacuum pouches made from polymer film (polyamide/polyethylene film thickness $60 \pm 3 \mu \mathrm{m})$.

\section{High pressure processing}

Samples of pork meat were treated in a highpressure processor ISO-Lab S-FL-100-250-09-W (Stansted Fluid Power Ltd., UK) with a pressure chamber of $2 \mathrm{~L}$ and a maximum operating pressure of $900 \mathrm{MPa}$. The pressure transmitting medium was a propylene glycol, water mix $(1: 2 \mathrm{v} / \mathrm{v})$ at room temperature. Vacuum-packed samples were randomly assigned to one of the six treatment pressures (50, $100,200,300,400$, and $500 \mathrm{MPa}$ ), while untreated sample served as the control. The HPP treatment for vacuum-packed samples at each pressure level was applied for three meat samples for durations of 1,5 , and 15 min respectively.

\section{Microbiological analysis}

Sample preparation for microbiological testing was performed in accordance with the standard method LVS EN ISO 6887-2:2004 'Microbiology of Food and Animal Feeding Stuffs - Preparation of Test Samples, Initial Suspension and Decimal Dilutions for Microbiological Examination - Part 2: Specific Rules for the Preparation of Meat and meat products'. Total plate count (TPC) was determined according to the standard LVS EN ISO 4833-1:2014 Microbiology of the Food Chain - Horizontal Method for the Enumeration of Microorganisms - Part 1: Colony Count at 30 Degrees $\mathrm{C}$ by the Pour Plate Technique using Nutrient (NA) agar (Ref. No 01-140-500), incubating at $30{ }^{\circ} \mathrm{C}$ for $48 \mathrm{~h}$ under aerobic conditions. After incubation, the colony forming units (CFU) were enumerated using the automated colony counter aCOLyte (Synbiosis, UK). All bacterial counts were expressed as the logarithmic (log 10) values. Microbiological analyses were completed in triplicate for all HPP treated and control samples.

\section{Determination of $\mathrm{pH}$}

Measurement of $\mathrm{pH}$ was done with a $\mathrm{pH}$ meter Jenway 3520 (Jenway, UK), which was calibrated against $\mathrm{pH}$ standard solutions 4.00 and 7.00. Procedure was done according to LVS ISO 2917:2004 method. It was measured for five repeats of each high pressure treated pork meat sample as well as for control sample.

\section{Determination of moisture}

Moisture of pork meat samples was determined using a standard method LVS ISO 1442:1997. Triple determinations of moisture content for each sample were carried out.

\section{Determination of water activity}

Six grams of minced meat sample was filled in a cup, placed in the LabSwift-aw unit (Novasina, Switzerland), and water activity was determined in triplicate for each sample (measurement range -0.11 to $0.99 \mathrm{a}_{\mathrm{w}}$, with an accuracy of $\pm 0.01 \mathrm{a}_{\mathrm{w}}$ ). Temperature during measurement was $22 \pm 1{ }^{\circ} \mathrm{C}$.

\section{Statistical analysis}

Results are presented as mean \pm standard deviation. The experimental data were analysed using Microsoft Excel 2014. Single factor analysis of variance (ANOVA) was used to compare the means. For data analysis, confidence level was $95 \%(\alpha=0.05)$. The factors have been evaluated as significant if p-value $<\alpha_{0.05}$.

\section{Results and Discussion}

The main purpose of meat products treatment at high pressure is to improve their microbial safety 
(Patterson, 2005). The most important challenge encountered in a high pressure pasteurization of food products is that the pressure resistance of microorganisms is reinforced in nutrient-rich media such as meat. The composition of the food matrix has been shown to influence the microbial results of a high pressure treated product despite the fact that the effect of each food constituent on pressure resistance is not well known (Simonin, Duranton, \& de Lamballerie, 2012).

The reduction of total plate count in pork meat as a result of the HPP treatment is presented in Figure 1. Individual species of microorganisms were not determined and evaluated in the frame of this research.

The total plate count determined in vacuum packed chilled pork was $2.99 \log _{10} \mathrm{CFU} \mathrm{g}^{-1}$ for the control sample. Microorganisms in meat demonstrated resistance up to $300 \mathrm{MPa}$ irrespective of treatment time. After undergoing high pressure treatment above $300 \mathrm{MPa}$, a significant $(\mathrm{p}<0.05)$ decrease of microorganisms was observed. Also other authors reported similar results with microbial inactivation at the range of $400-600 \mathrm{MPa}$ with short treatment duration (3 - $7 \mathrm{~min}$ ) (Del Olmo, Calzada, \& Nuñez, 2014). Similar to previous studies, it was confirmed that the TPC inactivation depends on the pressure applied. The TPC after the pressurization at $300 \mathrm{MPa}$ for $1 \mathrm{~min}$ was at the same level as in untreated control sample, being approximately $3.14 \log _{10}$ CFU g-1, irrespective of treatment time, but it was significantly reduced after treatment at $500 \mathrm{MPa}$ for $1 \mathrm{~min}$ to 2.17 $\log _{10} \mathrm{CFU} \mathrm{g}{ }^{-1}, 5 \mathrm{~min}-1.77 \log _{10} \mathrm{CFU} \mathrm{g} \mathrm{g}^{-1}, 15 \mathrm{~min}-$ $2.33 \log _{10}$ CFU g ${ }^{-1}$.

Nevertheless, results of the total plate count had no significant $(\mathrm{p}>0.05)$ difference between samples exposed to pressure for different duration of time. It shows that in the current experiment the lethality of microorganisms was more dependent on pressure applied not on the duration, the sample was exposed to pressure. However, it should be additionally noted that no significant reduction in the total plate count was found at pressures $50-300 \mathrm{MPa}$ for $1-15 \mathrm{~min}$. If pressure was further increased till $300-400 \mathrm{MPa}$, the reduction of viable microorganisms increased with the treatment time. Contrary, in meat treatment at $400-500 \mathrm{MPa}$ for more than 5 minutes, the efficacy was lower than that in samples treated for $1-5 \mathrm{~min}$. Bajovic, Bolumar, \& Heinz (2012) stated that the protein denaturation is one of the key mechanisms for microbial inactivation, and irreversible changes in muscle proteins start at a the same level which is required for the inactivation of microorganisms.

In general terms, applying higher pressures normally results in greater levels of vegetative cells reduction. However, in many cases the inactivation curves do not follow first-order kinetics, and a plot of hold time versus $\log 10$ survivors does not give a straight line. Tailing effects are common, with plots showing an initial decrease in numbers, followed by a levelling of the curve, where there is little further inactivation as treatment time increases (Patterson, 2014).

What is not less important, other authors mention that the microbial count is not reduced to the final effect immediately after the pressure treatment but shows a significant decrease during cold storage (Jofré et al., 2009; Simonin, Duranton, \& de Lamballerie, 2012). Analysing the information in scientific literature and experiments data, it can be concluded that the prior amount of microorganisms (contamination level) play very significant role in the meat, and the stages of microorganism development were important.

The $\mathrm{pH}$ values of meat and meat products generally range between 4.6 (raw fermented salami) and 6.4. The $\mathrm{pH}$ is an important factor in microbial load reduction, because microorganisms are the most pressureresistant at a neutral $\mathrm{pH}$ and become more sensitive

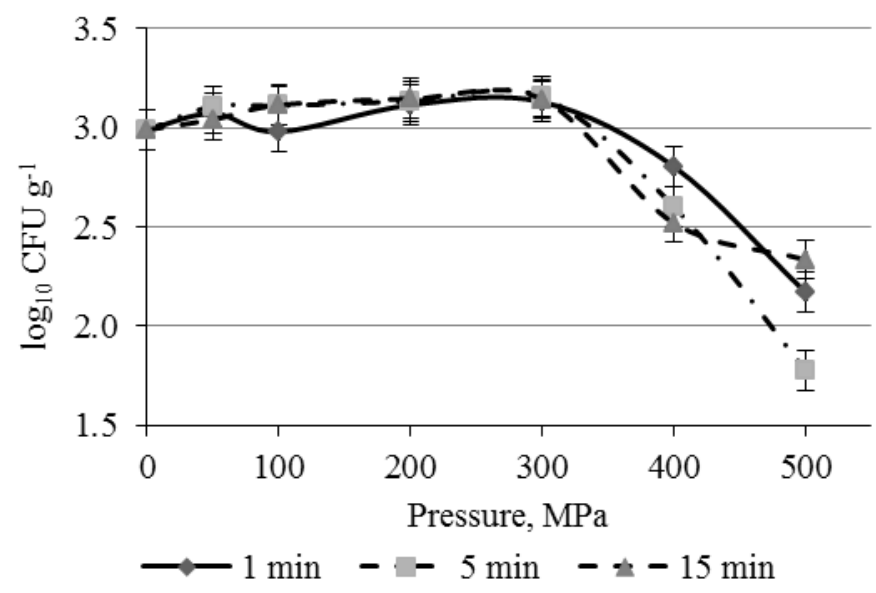

Figure 1. The total plate count (TPC) in pork meat samples depending on pressure and time of treatment. 


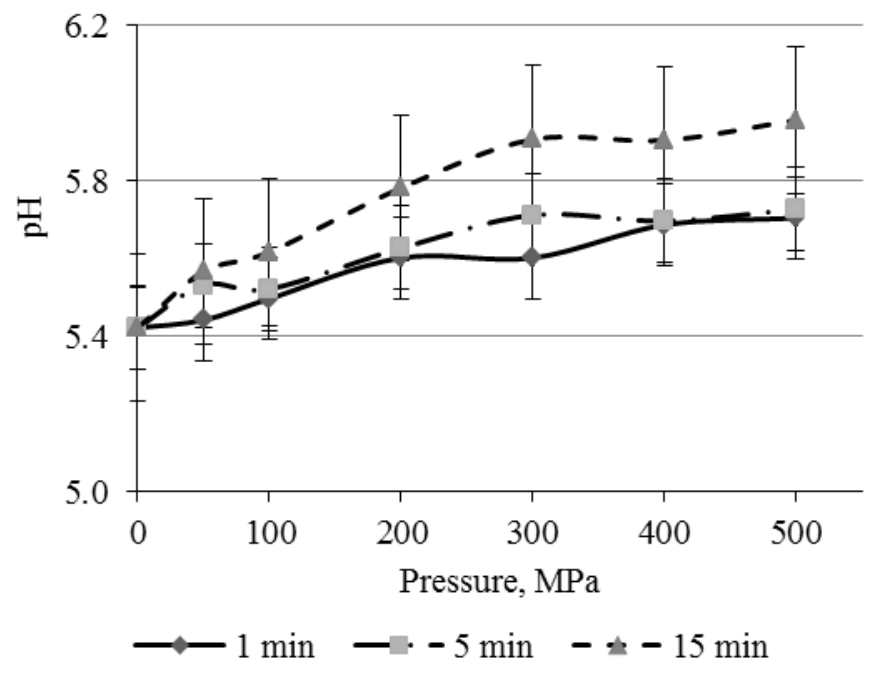

Figure 2. Effect of high pressure processing regime (pressure and time) on $\mathrm{pH}$ value of pork meat samples.

as the $\mathrm{pH}$ reduces. At a $\mathrm{pH}$ value of around 6.4 , meat is spoiled owing to enzyme activity, which produces a large amount of metabolic by-products as well as ammonia. Sliminess, bad smell and discolouration can be seen at this point as well. According to Vege and Bērzina (1999), pH value of pork immediately after debleeding is in the range of $6.6-6.8$; however, after $48-60 \mathrm{~h}$ it drops to $5.4-5.6$. In the current research it was determined that $\mathrm{pH}$ of chilled pork meat immediately after purchase was $5.51 \pm 0.06$ (Figure 2 ), while this value slightly decreased for meat after it was vacuum packed and reached $5.42 \pm 0.06$. Typical $\mathrm{pH}$ value for fresh meat did not change after treatment within the pressure interval from $50-200 \mathrm{MPa}$ and treatment time $1-5 \mathrm{~min}$. Similarly, for $15 \mathrm{~min}$ treatment at $50-100 \mathrm{MPa}$ the $\mathrm{pH}$ value was $5.6 \pm$ 0.04 , which corresponds to the value of fresh meat. Pressure treatment may induce reversible $\mathrm{pH}$ decrease as a result of the changing dissociation constants of attendant acids and bases (Stippl, Delgado, \& Becker, 2004). On the other hand, Ma and Ledward (2013) mentioned that the myofibrillar protein denatures under high pressure and at the same time, pressure increases ionization, sequestering free hydrogen ions and decreasing the acidic groups which corresponds to our results.

Figure 2 shows that an increase of pressure applied led to small but significant increases in $\mathrm{pH}$. Similar results were obtained by other authors who examined pressure treatment on beef meat $(\mathrm{Ma} \&$ Ledward, 2004), ovine meat (McArdle et al., 2013), tuna fish (Ramirez-Suarez \& Morrissey, 2006). Earlier researches have proved the slight increase in $\mathrm{pH}$ of post-rigor meat (by about $0.5 \mathrm{pH}$ units) immediately after the pressure treatment (Hugas, Garriga, \& Monfort, 2002; Sikes, Tornberg, \& Tume, 2010).
Comparing the obtained results of meat samples undergoing different exposure time, there was an increase of values; however, the difference was negligible $(p>0.05)$. High pressure application of $500 \mathrm{MPa}$ for $1 \mathrm{~min}$ increased $\mathrm{pH}$ to $5.70 \pm 0.02$, after $5 \mathrm{~min}-5.73 \pm 0.06$, and after $15 \mathrm{~min}$ of treatment it reached $5.96 \pm 0.03$. Ros-Polski et al. (2015) also reported that the $\mathrm{pH}$ values of chicken meat increased with increasing pressure, and there was no significant difference $(p>0.05)$ between the samples treated at 100 and $200 \mathrm{MPa}$.

The increase of $\mathrm{pH}$ in the heat treated samples is attributed to a rearrangement of meat protein structures as the proteins denature and unfold resulting caused by physical and chemical interactions induced by cooking (Hamm \& Deatherage, 1960). As the consequence of denaturation, the protein changes its configuration from a highly organized and native structure into a less organized (denatured) and nonnative structure. Other researchers hypothesised that although the structures established by high pressure and heating may be different, the mode of unfolding is similar (Ma \& Ledward, 2004). According to Messens, Van Camp, and Huyghebaert, (1997) protein unfolding is much less intense in pressurised samples in comparison to cooked samples.

The majority of water in muscle is held within the structure of the muscle itself, either within the myofibrils, between the myofibrils themselves and between the myofibrils and the cell membrane (sarcolemma), between muscle cells and between muscle bundles (groups of muscle cells) (HuffLonergan \& Lonergan, 2005). During increased pressure application on meat its molecules get closer to each other leading to the phase transitions which are reversible after depressurization (Hugas, 
Garriga, \& Monfort, 2002). Chilled pork moisture content before treatment was $79.0 \pm 1.0 \%$. Pressure application for different exposure times showed no significant difference between moisture content in the studied meat samples $(p>0.05)$. True reasons of high pressure effect on water binding properties of meat and meat products are still uncertain, and those are also controversial (Hygreeva \& Pandey, 2016).

The HPP can lead to the partial or total denaturation of protein structure due to the pressure induced unfolding of the protein structure and subsequent folding after pressure release (Bajovic et al., 2012). Increased pressure $50-500 \mathrm{MPa}$ can cause protein denaturation, which changes the structure and decreases the number of hydrophilic groups, which in its turn can reduce water binding and holding capacity. Rastogi et al. (2007) stated that major changes in the tertiary structure are observed beyond $200 \mathrm{MPa}$ and changes in secondary structure will take place only at a very high pressure above $700 \mathrm{MPa}$.

The results of the current study are in agreement with the research of Rastogi et al. (2007) who observed an increase in moisture content in the range of $100-200 \mathrm{MPa}$, which indicates small changes in tertiary structure of proteins. In the pressure range from $200-500 \mathrm{MPa}$, a decrease in moisture content was observed compared to the untreated sample. The moisture changes have been suggested as the myosin and actin of myofibrillar proteins were the major water-binding components in musculare tissue, and the rate of native myofibrillar protein aggregation and denaturation depends on pressure, temperature and ionic strength conditions (Sun et al., 2017).

Water activity is an important parameter affecting inactivation of microorganisms. Fresh meat exhibits an $\mathrm{a}_{\mathrm{w}}$ of around 0.98 , meaning that around $98 \%$ of the total water within meat is unbound whilst, at an $a_{w}$ of 0.80 , significantly less free water is present in a product.

It has been demonstrated that a low $\mathrm{a}_{\mathrm{w}}$ decreases the efficiency of high pressure treatments and in products with $\mathrm{a}_{\mathrm{w}} \leq 0.92$ cells are protected against pressure (Garriga et al., 2004; Jofré et al., 2009; Simonin, Duranton, \& de Lamballerie, 2012).

Fresh pork used in the current experiment had water activity $0.985 \pm 0.005$ on average. Water activity in the pressure treated pork samples at different exposure times was not considerably different $(\mathrm{p}>0.05)$.

\section{Conclusions}

High pressure processing is an effective method for reduction of microbial load in vacuum packed pork if the applied pressure is 400 or $500 \mathrm{MPa}$. In the present research, the treatment time did not show effect on microbial changes as the exposure time to high pressure showed significant difference. Pressure treatment affects meat $\mathrm{pH}$ and moisture content. For future research the changes of quality parameters of HPP treated chilled pork should be studied during its shelf life.

\section{Acknowledgements}

This research has been supported by National research programme 'Agricultural Resources for Sustainable Production of Qualitative and Healthy Foods in Latvia' (AgroBioRes) (2014 - 2017), project No. 4 'Sustainable use of local agricultural resources for qualitative and healthy food product development' (FOOD).

\section{References}

1. Aymerich, T., Picouet, P.A., \& Monfort, J.M. (2008). Decontamination technologies for meat products. Meat Science, 78, 114 - 129. DOI: 10.1016/j.meatsci.2007.07.007.

2. Bajovic, B., Bolumar, T., \& Heinz, V. (2012). Quality considerations with high pressure processing of fresh and value added meat products. Meat Science, 92(3), 280 - 289. DOI: 10.1016/j.meatsci.2012.04.024.

3. Balasubramaniam, V.M., Barbosa-Cánovas, G.V., \& Lelieveld, H.L.M. (2016). Pressure Processing of Food - Principles, Technology and Applications, New York: Springer Science+Business Media.

4. Del Olmo, A., Calzada, J., \& Nuñez, M. (2014). Effect of high pressure processing and modified atmosphere packaging on the safety and quality of sliced ready-to-eat "lacón", a cured-cooked pork meat product. Innovative Food Science and Emerging Technologies, 23, 25 - 32. DOI: 10.1016/j.ifset.2014.03.003.

5. Garriga, M., Grèbol, N., Aymerich, M.T., Monfort, J.M., \& Hugas, M. (2004). Microbial inactivation after high-pressure processing at $600 \mathrm{MPa}$ in commercial meat products over its shelf life. Innovative Food Science and Emerging Technologies, 5(4), 451 - 457. DOI: 10.1016/j.ifset.2004.07.001.

6. Hamm, R., \& Deatherage, F.E. (1960). Changes in hydration, solubility and charges of muscle proteins during heating of meat. Food Research, 25, 587.

7. Huff-Lonergan, E., \& Lonergan, S.M. (2005). Mechanisms of water-holding capacity of meat: The role of postmortem biochemical and structural changes. Meat Science, 71(1), $194-204$. DOI: 10.1016/j. meatsci.2005.04.022.

8. Hugas, M., Garriga, M., \& Monfort, J.M. (2002). New mild technologies in meat processing: high pressure as a model technology. Meat Science, 62(3), 359 - 371. DOI: 10.1016/S0309-1740(02)00122-5. 
9. Hygreeva, D., \& Pandey, M.C. (2016). Novel approaches in improving the quality and safety aspects of processed meat products through high pressure processing technology - A review. Trends in Food Science \& Technology, 54, 175 - 185. DOI: 10.1016/j.tifs.2016.06.002.

10. Jofré, A., Aymerich, T., Grebol, N., \& Garriga, M. (2009). Efficiency of high hydrostatic pressure at 600 $\mathrm{MPa}$ against food-borne microorganisms by challenge tests on convenience meat products. LWT-Food Science and Technology, 42(5), 924 - 928. DOI: 10.1016/j.lwt.2008.12.001.

11. Jofré, A., \& Serra, X. (2016). Processing of Meat Products Utilizing High Pressure. In: V. M. Balasubramaniam (Ed.), High Pressure Processing of Food (pp. 591 - 623), New York, USA: Springer Science+Business Media.

12. Jofré, A., Aymerich, T., Bover-Cid, S., \& Garriga, M. (2010). Inactivation and recovery of Listeria monocytogenes, Salmonella enterica and Staphylococcus aureus after high hydrostatic pressure treatments up to $900 \mathrm{MPa}$. International Microbiology, 13(3), 105 - 112. DOI: 10.2436/20.1501.01.115.

13. Keenan, D.F. (2016). Pork Meat Quality, Production and Processing on. In: B. Caballero, P. M. Finglas \& F. Toldrá (Eds.), Encyclopedia of Food and Health (pp. 419 - 431), Oxford, UK: Elsevier Ltd.

14. Ma, H.J., \& Ledward, D.A. (2004). High pressure/thermal treatment effects on the texture of beef muscle. Meat Science. 68(3), 347 - 355. DOI: 10.1016/j.meatsci.2004.04.001a.

15. Ma, H., Ledward, D.A. (2013). High pressure processing of fresh meat - Is it worth it? Meat Scence.; 95:897-903.

16. McArdle, R, Marcos, B., Mullen, A.M., \& Kerry, J.P. (2013). Influence of HPP conditions on selected lamb quality attributes and their stability during chilled storage. Innovative Food Science and Emerging Technologies, 19(3), 66 - 72. DOI: 10.1016/j.ifset.2013.04.003.

17. MacFarlane, J.J. (1985) High pressure technology and meat quality. In Developments in Meat Science, 3 ed. Lawrie, R. pp. 155 - 184. New York: Elsevier Applied Science.

18. Messens, W., Van Camp, J., \& Huyghebaert, A. (1997). The use of high pressure to modify the functionality of food proteins. Trends in Food Science and Technology, 8, 107 - 112.

19. Patterson, M.F. (2005). Microbiology of pressure-treated foods. Journal of Applied Microbiology, 98(6), 1400 - 1409. DOI: 10.1111/j.1365-2672.2005.02564.x.

20. Patterson, M.F. (2014). Food Technologies: High Pressure Processing. Reference Module in Food Science. Encyclopedia of Food Safety, 3, 196 - 201. DOI: 10.1016/B978-0-12-378612-8.00262-6.

21. Ramirez-Suarez, J.C., \& Morrissey, M.T. (2006). Effect of high pressure processing (HPP) on shelf life of albacore tuna (Thunnus alalunga) minced muscle. Innovative Food Science and Emerging Technologies, 7(1-2), 19 - 27. DOI: 10.1016/j.ifset.2005.08.004.

22. Rastogi, N.K., Raghavarao, K.S.M.S., Balasubramanaiam, V.M., Niranjan, K., \& Knorr, D. (2007). Opportunities and challenges in high pressure processing of foods. Critical Reviews in Food Science and Nutrition, 47, $69-112$.

23. Ros-Polski, V., Koutchma, T., Xue J., Defelice, C., Balamurugan, S. (2015). Effects of high hydrostatic pressure processing parameters and $\mathrm{NaCl}$ concentration on the physical properties, texture and quality of white chicken meat. Innovative Food Science and Emerging Technologies, 30, 31 - 42. DOI: 10.1016/j. ifset.2015.04.003.

24. Salvi, D., Gosavi, N.S., \& Karwe, M.V. (2016). High Pressure Cold Pasteurization. Reference Module in Food Science, DOI: 10.1016/B978-0-08-100596-5.21075-5.

25. Sikes, A.L., Tornberg, E., \& Tume, R.K. (2010). A proposed mechanism of tenderising post-rigor beef using high pressure-heat treatment. Meat Science, 84(3), 390 - 399. DOI: 10.1016/j.meatsci.2009.09.007.

26. Simonin, H., Duranton, F., \& de Lamballerie, M. (2012). New Insights into the High-Pressure Processing of Meat and Meat Products. Comprehensive Reviews in Food Science and Food Safety, 11, 285 - 306. DOI: $10.1111 / \mathrm{j} .1541-4337.2012 .00184 . x$.

27. Stippl, V.M., Delgado, A., \& Becker, T.M. (2004). Development of a method for the optical in-situ determination of $\mathrm{pH}$ value during high-pressure treatment of fluid food. Innovative Food Science and Emerging Technologies, 5(3), 285 - 292. DOI: 10.1016/j.ifset.2004.05.002.

28. Sun, X.D., \& Holley, R.A. (2010). High hydrostatic pressure effects on the texture of meat and meat products. Journal of Food Science, 75(1), 17 - 23. DOI: 10.1111/j.1750-3841.2009.01449.x.

29. Sun, S., Sullivan, G., Stratton, J., Bower, C., \& Cavender, G. (2017). Effect of HPP treatment on the safety and quality of beef steak intended for sous vide cooking. LWT - Food Science and Technology, 86, $185-$ 192. DOI: $10.1016 /$ j.lwt.2017.07.037.

30. Tonello, C. (2011). Case studies on high-pressure processing of foods. In: H.Q. Zhang, G.V. BarbosaCanovas, V., V.M. Balasubramaniam, C.P. Dunne, D.F. Farkas, \& J.T.C. Yuan(Eds), Nonthermal processing technologies for food (pp. 36 - 50), West Sussex: John Wiley \& Sons Ltd. 
31. Vege, A., \& Berzina, Z. (1999). Selection of pigs for lean meat. No: Catalog of varieties of pigs 98/99. Riga: Ministry of Agriculture of Latvia, 129 - 130.

32. Yordanov, D.G., \& Angelova, G.V. (2010). High Pressure Processing for Foods Preserving. Biotechnology \& Biotechnological Equipment, 24(3), 1940 - 1945, DOI: 10.2478/V10133-010-0057-8.

33. Zhou, G.H., Xu, X.L., \& Liu, Y. (2010). Preservation technologies for fresh meat - A review. Meat Science, 86, 119 - 128. DOI: 10.1016/j.meatsci.2010.04.033.

34. 30. Sun, S., Sullivan, G., Stratton, J., Bower, C., \& Cavender, G. (2017). Effect of HPP treatment on the safety and quality of beef steak intended for sous vide cooking. LWT - Food Science and Technology, 86, 185 - 192. DOI: 10.1016/j.lwt.2017.07.037. 